\title{
11 Representing the insane
}

\section{Introduction}

Studying facial expressions, that is to say, treating the face as a device that includes classifiable information on the way in which the person behaves, helps us to understand how this information is encoded and to develop a database of visual signs that could function as a guide to various behavioral practices. ${ }^{1}$ The effectiveness of this taxonomy, which constitutes the main principle of the art of physiognomy, presupposes that characterological traits are or become in a way innate, i.e. natural, and, as such, that they have a sympathetic relationship with the body. ${ }^{2}$

Bodily signs could be also examined as stereotyped modes of representing various types of insanity. Particular emphasis is given to the external traits of mental disorder, both in medical contexts and in physiognomic texts, i.e. to the peculiarity of facial expressions, eyes, and gestures, as these enable experts and laymen to distinguish between different types of mental disorders, and, generally, they signal imminent madness.

Within this framework, this paper will explore further how literary depictions of paintings and statues exploit physiognomic traits of madness to their advantage, i.e. to enroll enargeia, vividness for the described subject, trigger the viewer's phantasia and promote the artist's skills in presenting the aesthetic 'other'. ${ }^{3}$ Special attention will be given to the work of Callistratus, an orator of the fourth or fifth century CE, ${ }^{4}$ who often depicted heroes suffering from what is commonly described as mental disorder, including drunkenness and lovesickness.

\section{The physiognomic traits of insanity}

Physiognomic typology, as noted above, presupposes a natural interaction between body and soul and empirical observations for accessing mental dispositions. In the proemium of Ps. Arist. Physiognomonica it is stated: "that minds follow their bodies

1 On ancient physiognomy, see Evans 1941; Megow 1963; Klibansky, Panofsky and Saxl 1979, 55-66; Swain 2007; see further Métraux 1995, ch. 1.

2 Boys-Stones 2007, 19. See e.g. De alim. 23.1 on sympatheia in Hippocratic writings and Holmes 2014. 3 Cf. e.g. Quintilian, Inst. 6.2.29; Ps. Longinus 15.1. On phantasia and enargeia, see, among others, Zanker 2004, esp. ch. 3; Webb 2009, 93-96, 107-130; Platt 2011, 230-4; Vogt-Spira 2011; Roby 2016, 91 , Gross 1992, 167-170.

4 Cf. Nesselrath and Bäbler 2006, 4. 
and are not isolated and unaffected by the changes of the body is something that becomes very clear in cases of drunkenness and illness: for states of mind appear to change a great deal through the affections of the body. And correlatively, the body is clearly affected along with the affections of the soul in cases of love and fear and grief and pleasure"5 (cf. Arist. Prior Analytics 70b7-9); however, a non-innate, acquired affection or disease could be useful to physiognomists only in case it shows a very intense presence and thus manages to modify external bodily signs (see Ps. Arist. Phys. 806a7-12).

Mental disorders, such as cases of mania and of melancholy, are treated by physicians both as a permanent and non-permanent situation, a transient behavioral disorder and, at the same time, an enduring pathological condition. ${ }^{6}$ The Ps.-Aristotelian Problemata 955a39f. distinguishes between melacholia dia physin, a natural melancholy, and a non-temporary situation of melancholy which is the outcome of sickness (dia noson). When the black bile emerges from conditions outside the body (like diet) and is not part of the physique, then, it is merely a transient sickness and does not influence comportment and psychology, otherwise, the author of the treatise refers to a number of different types of melancholy, depending on the temperature and quantity of the black bile (953a29-32, 953b7-11, 954a22- 955a40; cf. further 953a15 on epilepsy). Galen in On the Temperaments 1, 643 also notes that some people are melancholic by nature. Mania in Ps. Arist. Physiognomonica, on the other hand, is not considered to be a chronic condition; nevertheless, it forces the body to adapt to it accordingly (808b23-28). ${ }^{7}$ However, in the Aristotelian Categories, manikẽ ekstasis is an inborn and permanent character trait (9b35-37). ${ }^{8}$ Caelius Aurelianus refers too to acute and chronic madness; for instance, mania is considered to be a chronic disease (Chron. 1.5), while phrenitis (Ac. 1.5, 1.21) and melancholy (Ac. 1.42) are described as acute diseases. ${ }^{9}$

Klibansky, Panofsky and Saxl argue that, despite the innate versus non-innate character of madness, a development of 'catalogues' with physiognomic symptoms of madness is observed in medical writings (cf. e.g. Hipp. Epidemics 2.5, 2.6); these do function as a heuristic tool for detecting and demonstrating madness. ${ }^{10}$ The somatic features of madmen, according e.g. to Rufus of Ephesos, include rigid eyes which can

5 Tr. by Swain 2007.

6 See, for example, Galen, De locis affectis 8 p. 156, 200, Oribasius, Collectiones medicae 45.30, 42, 45, 50, Ps. Galen, Definitiones medicae, 19.416. $\sigma \mu \sigma \tau, \sigma \mu \zeta$;

7 Iamblichus in De mysteriis 3, 25 argues that non-divine madness (the outcome of black bile, drunkenness, rage) is contrary to nature (para physin), while divine madness is greater than nature (hyper

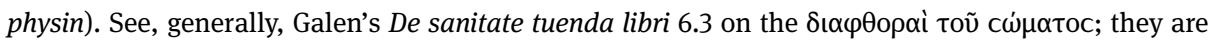

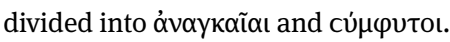

8 Ahonen 2014, 92.

9 See Brown 1993, 439f.; Van der Eijk 2013; cf. Boys-Stones 2007, 110; Gourevitch 2017.

10 However, see Boys-Stones 2007, 110. 
only blink, rough lips, brown skin color, ${ }^{11}$ little hairiness of the body, a delicate voice, rapid movement of the tongue when speaking, a large chest, but a narrow abdomen, gaunt limbs, fast and vigorous movements (see as in Aetius 9.56-151). ${ }^{12}$ Moreover, in the Hippocratic corpus, those with a melacholic type of madness stutter (Hipp. Epid. 2.5.1) or are affected by aphasia (Aph. 8.40, Morb. Sacr. 7.7-8; cf. ps. Arist. Probl. 953b13-16). ${ }^{13}$

Physiognomic texts use similar stereotypical features which signify the presence of insanity although in another context: open mouth, raised eyebrows, staring eyes, trembling eyes (Adam. A7), ${ }^{14}$ quivering eyes (Adam. A14), sparkling eyes (Adam. A16), dry eyes (Adam. A18), upturned neck (Adam. B21), spasms of the face and cheeks (Adam. B28), rough forehead (Adam. B21), deep voice which ends in a high pitched tone (Adam. B 42), flaming skin (Ps. Arist. Physiogn. 812a23-25), ${ }^{15}$ or a sullen look (Adam. B28), lean and wrinkled brows and drooping eyes (Phys. 808a7-12).

The most prominent, among the physiognomic traits of madness, that externalizes mental disorder into a shocking spectacle, is the extreme and convulsive mobility; in contrast, absence of movement defines cases of melancholy. The former feature enjoys a long tradition in Greek literature, best attested in the books of Mattes (1970), who calls it the syndrome of poriomania, and of Padel (1992), where she specifically argues, "inside is sane. Being 'out' of home and all it stands for - mind, right place is mad. Mad is outside, other, foreign" (1995, p. 15). ${ }^{16}$ Many mad characters in Greek tragedy, for instance, are engaged in the habit of making several different movements in quick sequence to, eventually, end in immobility and silence. ${ }^{17}$ Orestes' madness, as described by Euripides, provokes rapid movement (E. Or. 44f.; cf. 277f.); after madness is over, Orestes is merely a breathing image (155), a living corpse (385f.), with weak disjointed limbs, anarthros (228), in need of his sister's help in order to walk (218f., 231-234;

11 Finally, the association of dark skin with madness, as well as with phobos and depression (dysthy$\mathrm{mia}$ ), is common (cf. Aretaeus' On the causes and signs of chronic diseases 1.5.7), and this likely results from the role of black bile in the generation of madness. On that see, Gilman 1982, 2-3.

12 See also Rufus, On Melancholy preserved by Rhazes, as cited by Klibansky, Panofsky and Saxl 1979, 49 n. 128.

13 Flashar 1966, 47, n. 59-60 for further examples. See also: Orestes (Eur. Or.) is both speechless and

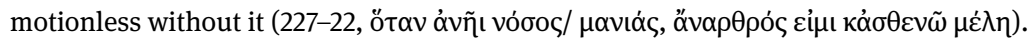

14 For the purposes of this article I follow Repath's 2007 line of thought regarding the text of Adamantius.

15 Particularly, the Leiden Polemon in B51, on the signs of a depressed and sad man, reports: "His sign is that you see he has a peeling face, bringing together what is between the eyes, with a huge forehead, eyebrows locked together, a furtive gaze, eyelids joined together, and frightened by fear"; tr. by Hoyland 2007.

16 On madness as it is associated with wandering, see Mattes 1970, 63-64.; Padel 1981, 112 and 1995, 99-100, 107-108; Montiglio 2005, 27-28; Becker 1937, 156-157 (esp. for Aeschylus).

17 See further characters affected by physical illness; they can be distinguished by slow motion or non-motion at all (cf. the ill body of Philoctetes in Sophocles' Phil. 207). 
cf. S. Phil. 879-881). ${ }^{18}$ The frenetic movement and the shaking of the head and hands that mad persons exhibit, stand in opposition to gestures that are codified, dignified, slow and calm, movements that, for example, the Athenian aristocrats of the classical period had to adopt in order to bolster their status (cf. S. Thyestes fr. $257,{ }^{19}$ although cf. Phrynichus fr. 10 K.-A.). ${ }^{20}$

Madness, mainly its manic type, is expressed through disorderly movements and disconnected gestures, both in medical and physiognomic texts too. In the On the sacred disease 15, the author, describes two types of insanity, the phlegmatic (due to an excess on phlegma) and the choleric (due to an excess of cholẽ): the phlegmatic type is quiet and does not warp, while the choleric type cries, is aggressive and restless, and is always doing something inappropriate. ${ }^{21}$ At $1.90-3$, the patient, during a mad crisis, is reported to be jumping from his bed and rushing out of doors (cf. 7.14-32).22 Moreover, the text of the Physiognomonica warns that, to reach a diagnosis, one should take into consideration not only facial traits but also the kind of movements which take place and the signs of the body postures (806a28, हैk $\tau \varepsilon$

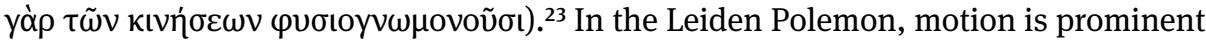
among physiognomic signs of madness (B39). Particularly, in B58, it is argued that other signs of an evil and stupid madman are, along with weakness of knees, an excessive preoccupation with looking at himself and the limbs of his body, a reedy, sharp, long voice, and excessive movement of his head. Attention to movement also embraces the minutiae of leg behavior. More precisely, in B7, the author argues that those with thick ankles, thick heels, fleshy feet, stubby toes, and thick calves are, for the most part, either stupid or mad.

18 See further Euripides' Heracles: Madness causes his muscles to contract violently (953); according to Lyssa he is tossing his head, rolling his eyes and cannot control his breath (990). In v. 931, it is

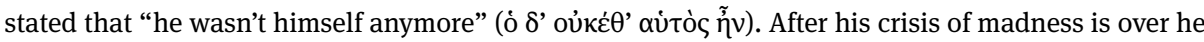

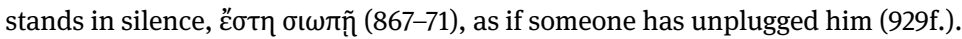

19 As cited at Bremmer 1991, 19.

20 See Bremmer 1991, 18-18.

21 See Flashar 1966, 29-30.

22 Cf. the idea that the womb moved freely within a woman's body, causing madness, is attested in the classical period in Plato's Timaeus 91b-e and in the early Hippocratic text Diseases of Women 2.201. See further, Aretaeus of Cappadocia, On the Causes and Symptoms of Acute Diseases 2.11.1, Therapeutics of Acute Diseases 2.11; Soranus, Gynecology 3.29, Galen, On the Affected Parts 6.5, On the Anatomy of the Womb 4. See, on the wandering uterus, among others, Dean-Jones 1994, ch. 1; King 1993 and 1998, ch.11.

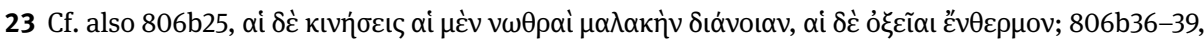
807b28-29, 35-36, 808a11-12 


\section{Portrayals of insanity}

The orator's representation of mental disorders in an ekphrasis corresponds to culturally acquired knowledge, already residing in his audience's memory. ${ }^{24}$ That is to say, it could also rely on established formulas, standardized visual symbols and external attributes of madness represented both in medical and physiognomic context. Taking advantage of the facial typology of various types of emotional characters as a visual resource that, consequently, would have a communicative effect on its audience, ${ }^{25}$ writers of ekphrastic depictions convey a sense of lived experience to their audience. Moreover, while the depiction of physiognomic traits of madness and descriptions of the painted or sculpted body of the madman provide a representation of mental disorder and advance a guide to illness. In contrast to medical and physiognomic texts, the physiognomic characteristics of mad bodies in ekphrasis mark madness as a positive aesthetic and ontological value and, ultimately, invite the audience to develop a sympathetic relationship with the aesthetic 'other' ${ }^{26}$ Representing emotional excess, the mad body is depicted in ekphraseis neither as contemptible nor as alien; on the contrary, it becomes a source of knowledge concerning the darker sides of human existence, probably also under the influence of famous literary scenes of madness in Greek epic or tragedy (cf. Ps.-Arist. Probl. 953a10-26). ${ }^{27}$

Portraying mental illness gives the artist the opportunity not only to imitate nature, but to imitate it in a non-typical state. The madman's soul is overloaded with emotions, and his facial and bodily expressions are quite demanding. He experiences extreme sensations and, due to this, various constantly-changing emotions are imprinted on his face which is depicted as deformed. Depictions of madmen offer, then, a bodily reality that is changed, sometimes corrected or supplemented, and, as such, produces additional vividness according to the unexpectedness that the viewer experiences. For instance, in description 2, where Callistratus describes the manic Bacchante, her femininity is described as a corrected one (diorthoumene), as the traditionally feminine passivity is replaced with speediness and strength generated by the mania given to her by Dionysus.

At the same time, the representation of madness in the verbal descriptions of art gives the impression that it challenges the limits of naturalism. The portrayal of mania functions as a case study for this particular issue, namely of the artistic tendency to externalize the natural case, here of insanity, without abandoning the capacity of art to expand perception. This is probably supported by the character

24 See Bartsch and Elsner 2007; Webb 2009, 109-110.

25 See Webb 2009, ch. 5.

26 Cf. Elsner 2007a, 204.

27 See Padel 1995. 
of mania itself which is described by Philostratus the Elder as a deceptive mechanism that is prone to draw someone away from things that exist to things that

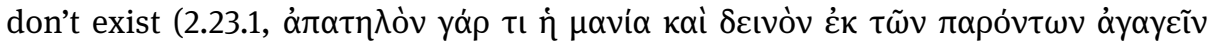

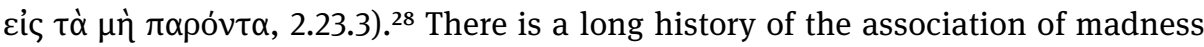
with illusion and against realism. For example, in the play of Euripides' Orestes, the protagonist in his mad moments vividly describes the hunt of the Erinyes ${ }^{29}$ (he constantly changes from $\varepsilon^{\prime} \mu \varphi \rho \omega \nu$ to $\alpha{ }^{\prime} \rho \rho \omega \nu$, cf. Or. 43-45, 253-254, 29730), creating an additional, alternative stage where he supposedly fights with the monsters (268-

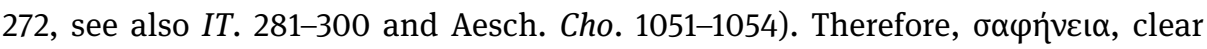
knowledge, does not prevail on this stage, as his sister Electra says (Or. 258-259,

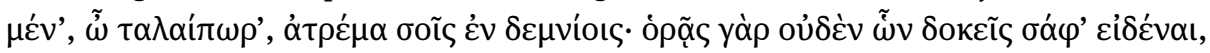
cf. 976-981). ${ }^{31}$

Ruth Webb, in her book Ekphrasis, Imagination and Persuasion in Ancient Rhetorical Theory and Practice, refers to the work of an anonymous writer, entitled Peri ton tessarõn merõn tou teleiou logou, where the text describes the difference between simple and elaborate narrative by drawing on the episode of Ajax's madness (Walz, Rhetores Graeci, vol. 3, pp. 576-578), which is contracted to simple narrative, since, the elaborated narrative reveals the hero's signs of madness: "He indicated (menuei) his inner feelings by his wild appearance, by the ruthless and hot-blooded look in his eyes as well as by his fast and deep breathing [...]. He moved at one moment with stealthy control and at the next he moved quickly in his rage - long was the stride of the gigantic hero - but Athena diverted both his mind and his eyes, darkness fell on his inner and his outer vision". ${ }^{32}$

Hence, madness gives the opportunity to both the artist and the orator to expose their technical and artistic virtuosity by proving that it is possible to transform the invisible into words and images by mimicking nature in order to reach not only anatomical realism, but, more importantly, emotional realism. ${ }^{33}$ In the main, the representation of the unseen, as in the techne of physiognomy where the visible signs of the body stand for the invisible character traits, or in the art of medicine where the

28 The action of viewing and being deceived is a central figure of several other pictures in the Imagines (cf. 1.23, on Narcissus); see Elsner 2007, 325. On aesthetic deception see, among others, Halliwell 2002, 1-33, Wessels 2014, Woodruff 2015.

29 Cf. also Cho. 1061, Orestes is the only one who experiences a true vision of Erinyes, whom he is able to describe vividly (1048-1050, 1057-1058).

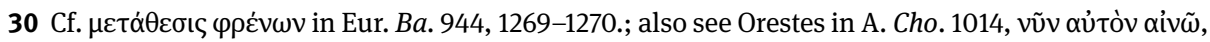

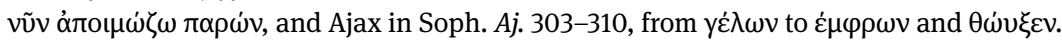

31 Gerolemou 2011, 7.

32 Webb 2009, 209-210.

33 On anatomical realism in art, see Métraux 1995, 13-14. For the emotional realism of Hellenistic art, see, among others, Pollitt 1986, 141-147; Neer 2010, ch. 4. 
interior space of the body is revealed through symptoms, ${ }^{34}$ becomes a matter of urgent concern for art as well, especially from the Hellenistic period and onwards. This kind of representation valorizes art's ability to exercise mastery over physical forces and passions. In the Memorabilia, Socrates supports the concern of the figurative arts to convey all kinds of emotions and emotional conflicts (Mem. 3.10; Pliny NH 35.98). Similarly, the younger Philostratus argues that the accomplished painter must be able

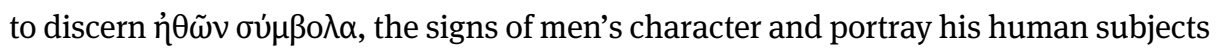
as insane or angry, thoughtful, happy, or in love (Imagines 1, Proem. 3). ${ }^{35}$ Callistratus argues too that art has the tendency to express or represent the unseen passions and character (cf. Descr. 10.2). ${ }^{36}$ For example, depiction 4 presents the statue of a drunken Indian who exhibits signs of mania because of excessive drinking. According to Ps.Arist. Probl. 953a34-953b9 the amount of wine that one drinks could turn someone into a manic or demented (moros) person, epileptic, or someone suffering from melancholy. More precisely, the text claims that mania and drunkenness are both accompanied by excessive bodily heat, so that the man, whether drunk or mad, is unable to think or to have appropriate sense perceptions (957a3). ${ }^{37}$ However, the sculptor, according to Callistratus, fails to portray drunkenness and mania and thus make the cheeks of the Indian flesh-red to signal that he is overwhelmed by his drunkenness; his condition is rather portrayed through the Indian's trembling posture. At the same time, however, literary portraits of insanity underline the fact that the reading of facial expressions and, generally, of bodily behavior depends not merely on what the expressing subject feels, but on what the audience feels when it reads/sees it; thus, in this context, the line of demarcation between sanity and insanity depends upon the audience's interpretation as well; I will touch this point further at the end of chapter.

In Callistratus' depictions of sculpted and painted heroes in frenzy, medical and physiognomical signs of madness are mingled with literary portraits of madmen. For instance, Praxiteles' statue of Dionysus is influenced, according to Callistratus' text, by the image of the youthful Dionysus-Stranger of Euripides' play Bacchae, where the god is pictured as a young man, full of daintiness and desire (Dep. 8.3) and with gleaming eyes, exhibiting in this way the Bacchic mania (8.5). Similarly, in Depiction 2, Callistratus, although he does not describe the actual signs of madness which are imprinted on the face of a Bacchante and does not refer to any literary ancestors, reports:

34 See Holmes 2010.

35 Lysippus, according to Plutarch, was chosen by Alexander as the only one who could depict his character (Plut. Alex. 4.1-2).

36 See, for further discussion, Lada-Richards 2003, 15-16.

37 On drunkenness as a type of madness, see Caelius Aurelianus (Chron. 1.5.146) and Areateus, On the causes and signs of chronic diseases 1.6. For drunkenness as a "minor case of madness", see Chrysippus in Stobaeus 3, 18, 24. See also Seneca, Epistle 83, 18 who describes drunkenness as "voluntary madness" (voluntaria insania). 
When we saw the face we stood speechless; so manifest upon it was the evidence of sense perception, though perception was not present; so clear an intimation was given of a Bacchante's divine possession aroused it; and so strikingly there shone from it, fashioned by art in a manner not to be described, all the signs (tekmeria) of passion which a soul goaded by madness displays (2.3). ${ }^{38}$

Callistratus' reaction to the sight of madness is a narrative device for ensuring sympathy with the mad Bacchante by placing the audience in the artist's and narrator's position. ${ }^{39}$ Particularly, the hands of the Bacchante are pictured in action (energous epedeiknuto) while she is shaking their Bacchic thyrsus and carrying her victim (2.4). The Bacchante is noisy and restless, disturbing everyone around her (cf. Morb. sacr. 15. 3-5). Furthermore, the detailed description of her wavy loose hair (2.3), reminiscent of the manic Euripidean Phaedra in Hippolytus (201-201), denotes mania too. Finally, the decline of the mental faculties is further illustrated with the dullness of her eyes. Philostratus the Elder also provides a picture of the Bacchantes (1.18) during their violent act of murder, rending in pieces Pentheus and tearing off his arms, while Agaue is dragging her son by the hair. Pentheus is begging them not to kill him, but they only hear a lion's roaring. In Cithaeron, they rush headlong, setting in motion echoes from the mountain side.

The statue of Medea constitutes an exegesis of her drama as told by Euripides (Dep. 13). Deserted by her spouse, Medea goes into a state of delirium suddenly and exhibits a profound alteration of facial expression: The statue expresses emotions and actions that are first rational and then passionate, and generally negates,

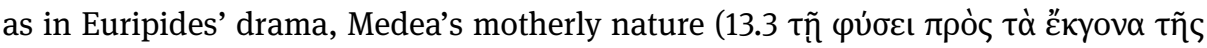

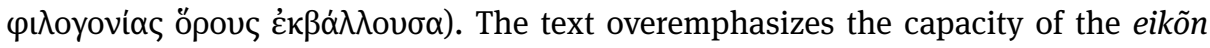
to imitate Medea's emotions, which rapidly change from reasoning (logismos) to passion (thymos) and eventually grief (lupẽ $)^{40}$ which, in Callistratus' text, is reproduced through constant mood swings. Rushed motion is exemplified by Seneca, in his Medea play, as the most important sign of the protagonist's madness (382-386), which, in Callistratus' text, is reproduced through constant mood swings. Ultimately, her changing feelings lead to her act of murder. Her grief, at the place of her thymos, depicts her solely in terms of her motherly instincts, which, because they are weak (arrõstos), cannot prevent her from murdering her children. However, both her animal-like passion and tenderness are described as products of the complicated female nature. After her cholos becomes thymos, anger, she returns, naturally, to pity (oiktos).

In her despondency, her face is flushed, she is induced to silence, she loses her appetite, and she lies unmoving. In particular, she is pale, depressed and not

38 All translations of Callistratus are from Fairbanks 1931 (Loeb).

39 On sympathy as a working tool of ekphrasis, see Webb 2009, e.g. p. 149.

40 Likewise, in Seneca's drama, madness, among other passions, is imprinted on her face (Medea

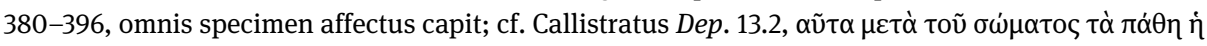

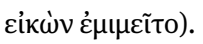


concerned with cleanliness or decency. Her depressive variety, $\delta v \sigma \theta v \mu$ ín of lovesickness, violence or anger, and reasoning is further impressed in her mourning pose, as pictured first in her hands, holding the murder weapon (a sword) ready to serve her mad passion, then, in her dark-cloak, and generally in her careless appearance, unkempt hair and dirty clothes (cf. Hipp. Aph. 6.23 and Galen on Medea in On the Doctrines of Hippocrates and Plato, e.g. 3.4.23). Her actions are vague and uncertain, performed without energy or volition. More importantly, her eyes, in some instances, exhibit her passion, in others her morose disposition (skythrõpon), which then transforms into sadness (stygnotês). This twofold situation is also found in the epigrammatist Antipholus of Byzantium (AP 16.136), who describes Timomachus' painting of Medea in her two dispositions, angered and in a state of pity. The bloodshot eyes, which flash murderous fire, are recruited to indicate madness (AP 16.135-43) along with Medea's murderous hands (AP 16.128). ${ }^{41}$ Medea's eyes, as a sign of her homicidal madness, were previously described by Euripides, in his Medea, when she looks at

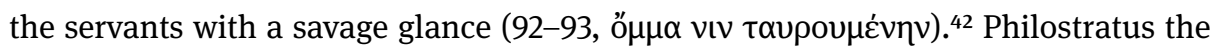
Younger delivers a similar description of a painting of Medea. According to him, there is a grim frown around her eyes, and her brow is charged with deep thought. Her hair is bound in a hieratic way while her eyes are shining, either with love or inspiration, divine mania (7.1). Describing mad Heracles, Philostratus the Elder uses analogous stereotypical features: the hero in madness smiles "a grim and alien smile" (2.23.3), ${ }^{43}$ his eyes are fixed, and he has no consciousness; external impressions make very little impression upon his mind; consequently, the power of volition is diminished.

Callistratus finds the painting of Athamas (Dep. 14), a favorite tragic character, on the shores of the Scythian land after the murder of his son Learchus. The mad Athamas, king of Orchomenos, is captured naked, with blood in his hair. His hair, like the hair of the Bacchante, is flying in the wind, a sign of furious movement, while his eyes are distressed (paraphoros) and filled with anxiety (ekplẽxis). He is armed, but only with madness (mania), for his raged deed and soul-destroying fear (thymophtoron deima) sent by the furies. Additionally, like Medea, he holds a sword ready to rush out (probeblẽto ektheonti) and, although he is not moving (akinẽtos), a sense of movement is conveyed which sparks bewilderment, displacing in this way those who experience it (tous theatas existê). In this painting, Ino is depicted as terrified, trembling from fear, and pale as if she is dead. According to the Physiognomists, pale eyes are also perceived as a sign of madness (Anonymi Medici, 3.5, ó $\varphi \theta \alpha \lambda \mu$ oì

41 Cf. Timomachus for illustrating Medea in a moment of visual calmness before violent action and Gutzwiller. Philostratus (V.A. 2.22) tells us that Timomachus' Ajax was shown, after the attack on the flocks, sitting in dejection and planning his suicide.

42 Similarly, Clytemnestra in Depiction 10 of Philostratus (Book 2) appears equally mad: her eyes are crazed, her hair are flying, her savage arm with the axe is turning against Cassandra. On the eyes as bearer of emotions in Greek culture, see Cairns 2005.

43 Tr. by Fairbanks 1931 (Loeb). 


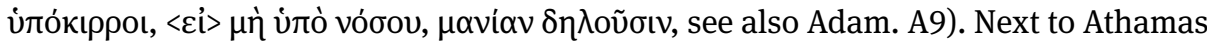
and Ino, the picture is supplemented with Amphtrite and the Nereids. The eyes of the former, as they glance, are savage and fearsome, conjuring her with madness, while the latter are full of himeros, desire, amazing in this way the spectator.

The perceivers of a madman's story visualize various settings which rapidly change as the story develops. That is to say, they are forced to adjust to the real and emotional movement of the mad character under description. Euripides, by underlining motion as a feature that signifies madness, describes Heracles' madness in this way: Heracles thinks that he undertakes a journey to Megara (954-955) where he joins a banqueting hall (955-957), then approaches the Isthmos (958) and ends his travels

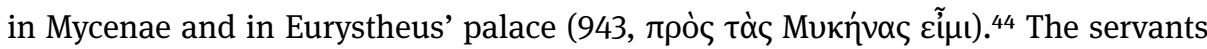
staring at the spectacle are confused and thus ask: 'Does our lord play a game with us or is he insane?' (952). The motion produced by Heracles' madness is employed to add dynamism to the scene by stimulating an illusion of wider space. More madness, more space! Moreover, the fact that madness usually creates upheaval in the scene by attracting spectators gives the impression that the artwork is alive and keeps the audience's eyes engaged. For instance, the mad Athamas and Heracles, examined above (see also Philostratus the Elder 2.23), are surrounded by observers of the manifestations of their insanity (who also try to help them fight their madness), the servants in Heracles' case, Ino, Amphitrite and the Nereids in Athamas' case. Consequently, such an elaborated description emphasizes, as I argued briefly above, not only the emotions felt by the characters in insanity, but moreover those aroused sympathetically in both the intra- and extranarrative audience.

\section{Conclusion}

Descriptions of madness in medical and physiognomic contexts rely on typified bodily and behavioral signifiers, especially motion, for achieving a precise diagnosis and understanding of the signaling of insanity. Writers of ekphrasis too, particularly Callistratus, depict the insane mind and body by using physiognomic traits. Notably, this not only serves the purpose of advancing artistic naturalism; the depiction of madness both as visceral and as artistic excessiveness works sympathetically towards the audience. In other words, portrayals like this elicit the audience's sympathy for the 'oddity' of both mad mind and body and, ultimately, urge the acceptance of it as an aesthetic alternative.

44 See also in HF 1197, his travel, insane, across the river Acheron into Hades. Cf. further on Heracles' travelling Kraus 1998, 152. 


\section{Bibliography}

Ahonen, M. 2014. Mental Disorders in Ancient Philosophy. Heidelberg.

Bäbler, B., and Nesselrath, H.-G. 2006. Ars et verba: Die Kunstbeschreibungen des Kallistratos. Munich.

Bartsch, S., and Elsner J. 2007. "Introduction: Eight Ways of Looking at an Ekphrasis". In: Classical Philology 102(1), i-v.

Becker, O. 1937. Das Bild des Weges und verwandte Vorstellungen im früh-griechischen Denken. Berlin.

Boudon-Millot, V. 2013. "What Is a Mental Illness and How Can It Be Treated? Galen's Reply as a Doctor and Philosopher”. In: W. V. Harris (ed.), Mental Disorders in the Classical World. Leiden, 129-145.

Bremmer, J. N. 1991. "Walking, Standing and Sitting in Ancient Greek Culture”. In: J. N. Bremmer \& H. Roodenburg (eds.), A Cultural History of Gesture. Ithaca, 15-35.

Cairns, D. 2005. "Bullish Looks and Sidelong Glances: Social Interaction and the Eyes in Ancient Greek Culture”. In: D. Cairns (ed.), Body Language in the Greek and Roman Worlds. Swansea, 123-155.

Kraus, C. S. 1998. “Dangerous Supplements: Etymology and Genealogy in Euripides' Heracles”. In: Proceedings of the Cambridge Philological Society 44: 137-158.

Roby, C. A. 2016. Technical Ekphrasis in Ancient Science and Literature: The Written Machine between Alexandria and Rome. Cambridge.

Dean-Jones, L. 1994. Women's Bodies in Classical Greek Science. Oxford.

Elsner, J. 2007. "Philostratus Visualises the Tragic: Some Ekphrastic and Pictorial Receptions of Greek Tragedy in the Roman Era”. In: C. Kraus, H. Foley, S. Goldhill and J. Elsner (eds.), Visualising the Tragic. Oxford, 309-337.

Elsner, J. 2007a. "Physiognomics: Art and Text”. In: S. Swain (ed.), Seeing the Face, Seeing the Soul: Polemon's Physiognomy from Classical Antiquity to Medieval Islam. Oxford, 203-224.

Evans, E. C. 1941. "The Study of Physiognomy in the Second Century A.D.". Transactions and Proceedings of the American Philological Association 72: 96-108.

Flashar, H. 1966. Melancholie und Melancholiker in den medizinischen Theorien der Antike. Berlin.

Gerolemou, M. 2016. “Homeric and Tragic Madness”. In: E. Perdikogianni-Paleologou (ed.), The Concept of Madness from Homer to Byzantium: History and Aspects. Amsterdam, $1-34$.

Gilman, S. L. 1982. Seeing the Insane: A Cultural History of Madness and Art in the Western World, Showing How the Portrayal of Stereotypes has Both Reflected and Shaped the Perception and Treatment of the Mentally Disturbed. New York.

Gourevitch, D. 2017. "Madness and Mad Patients According to Caelius Aurelianus". In: C. Laes (ed.), Disability in Antiquity. Rewriting Antiquity. London, 283-297.

Gross, K. 1992. The Dream of the Moving Statue. London.

Gutzwiller K., "Seeing Thought: Timomachus' Medea and Ecphrastic Epigram”, American Journal of Philology 125 (2004), 339-386.

Holmes, B. 2014. "Proto-Sympathy in the Hippocratic Corpus". In: J. Jouanna and M. Zink (eds.), Hippocrate et les hippocratismes: médecine, religion, société: Actes du XIVe Colloque International Hippocratique. Paris, 123-138.

Holmes, B. 2010. The Symptom and the Subject: The Emergence of the Physical Body in Ancient Greece. Princeton.

King, H. 1993. "Once Upon a Text: Hysteria from Hippocrates”. In: S. L. Gilman, H. King, R. Porter, G. S. Rousseau \& E. Showalter (eds.), Hysteria Beyond Freud. Berkeley, 3-90. 
King, H. 1998. Hippocrates' Woman: Reading the Female Body in Ancient Greece. New York; London, Routledge.

Lada-Richards, I. 2003. "Mobile Statuary: Refractions of Pantomime Dancing from Callistratus to Emma Hamilton and Andrew Ducrow". In: International Journal of Classical Tradition 10.1, 3-37. Mattes, J. 1970. Der Wahnsinn im griechischen Mythos und in der Dichtung bis zum Drama des fünften Jahrhunderts. Heidelberg.

Megow, R. 1963. “Antike Physiognomielehre”. In: Das Altertum 9, 213-221.

Métraux, G. P. R. 1995. Sculptors and Physicians in Fifth-Century Greece: A Preliminary Study. Montreal. Montiglio, S. 2005. Wandering in Ancient Greek Culture. Chicago.

Neer, R. T. 2010. The Emergence of the Classical Style in Greek Sculpture. Chicago.

Padel, R. 1981. "Madness in Fifth-century Athenian Tragedy". In: P. Heelas \& A. Lock (eds.), Indigenous Psychologies. The Anthropology of the Self. London, 105-131.

Padel, R. 1992. In and Out of Mind: Greek Images of the Tragic Self. Princeton.

Padel, R. 1995. Whom Gods Destroy: Elements of Greek and Tragic Madness. Princeton.

Platt, V. J. 2011. Facing the Gods: Epiphany and Representation in Graeco-Roman Art, Literature and Religion. Cambridge.

Klibansky, R., E. Panofsky, and F. Saxl. 1979. Saturn and Melancholy Studies in the History of Natural Philosophy, Religion and Art. Nendeln.

Swain, S. (ed.) 2007. Seeing the Face, Seeing the Soul: Polemon's Physiognomy from Classical Antiquity to Medieval Islam. Oxford.

Van der Eijk, P. J. 2003. "Cure and (In)curability of Mental Disorders in Ancient Mand Philosophical Thought”. In: W. V. Harris (ed.), Mental Disorders in the Classical World. Leiden, 307-338.

Vogt-Spira, G. 2011. "Prae sensibus. Das Ideal der Lebensechtheit in römischer Rhetorik und Dichtungstheorie”. In: G. Radke-UhImann \& A. Schmitt, Anschaulichkeit in Kunst und Literatur. Wege bildlicher Visualisierung in der europäischen Geschichte. New York, 13-34.

Webb, R. 2009. Ekphrasis, Imagination and Persuasion in Ancient Rhetorical Theory and Practice. Farnham and Burlington.

Woodruff, P. 2015. “Mimesis”. In: P. Destrée \& P. Murray, A Companion to Ancient Aesthetics. London, 329-340.

Zanker, G. 2004. Modes of Viewing in Hellenistic Poetry and Art. Madison. 